\title{
Análise da qualidade de vida dos pacientes do grupo de quadril adulto operados com enxerto ósseo
}

Analysis of the quality of life of patients of the adult hip group operated with bone graft

\author{
Vera lucia Frazão de Sousa ${ }^{1}$, Rosângela Suarti dos Reis², Antonio Carlos Bernabé ${ }^{3}$
}

\section{RESUMO}

O Banco de Tecidos do IOT-HCFMUSP tem o objetivo de captar e processar tecido ósseo, cartilagem e ligamentos, com a finalidade de beneficiar o maior número possível de pacientes. Constituído por médicos, enfermeiros e assistente social, o programa visa ainda propiciar aos receptores a reabilitação física e social com a perspectiva de lhes oferecer uma melhor qualidade de vida. Realizou-se um estudo objetivando conhecer os benefícios e mudanças ocorridas com o tratamento cirúrgico e analisar se a expectativa bem como a melhoria na qualidade de vida dos pacientes foram atingidas. Os dados apontam que $37,5 \%$ da população pertence à classe $C, 37,5 \%$ classe D e $25 \%$ classe $E$. O suporte familiar foi satisfatório para $81,25 \%$ da população, sendo que $37,5 \%$ apresentaram rendimento mensal regular ou insatisfatório para 0 tratamento. Das dificuldades apresentadas anterior à cirurgia $93,75 \%$ dos pacientes apresentaram dor, o que causava limitações físicas e dificuldades de locomoção nas Atividades da Vida Diária. $100 \%$ dos pacientes consideraram que a cirurgia trouxe benefícios para sua qualidade de vida e destes $56,25 \%$ aboliram os equipamentos ortopédicos que faziam uso, relatando ausência de dor. Concluímos que o tratamento proporcionado pela equipe tem trazido benefícios e resultados significativos para a melhoria da qualidade de vida dos pacientes.

Descritores: Transplante ósseo; Qualidade de vida.

\section{ABSTRACT}

The objective of the Tissue Bank of the IOT-HCFMUSP (Institute of Orthopedics and Traumatology, Clinics Hospital, Faculty of Medicine, University of Sao Paulo, SP-Brazil) is to collect and process bone tissue, cartilage and ligaments, with the purpose of providing benefits to the largest possible number of patients. The program is formed by physicians, nurses and assistant social worker, viewing to provide those who receive it with physical and social rehabilitation, with the perspective of providing them with a better quality of life. A study was performed with the objective of knowing the benefits and changes occurred regarding surgical treatments and analyze whether the expectation, as well as the improvement in the patients' quality of life, were achieved. The data indicate that $37.5 \%$ of the population is included in the $C$ class; $37.5 \%$ in the D class and $25 \%$ in the E class. Family support was satisfactory in $81.25 \%$ of the population, and $37,5 \%$ had monthly incomes that were either regular or unsatisfactory to the treatment. As to the difficulties presented previous to the surgery, $93.75 \%$ of the patients had pain that caused physical limitations and locomotion problems in Daily Life Activities. One hundred percent of the patients considered that the surgery brought benefits to their quality of life; $56.25 \%$ of these patients abandoned the orthopedic equipment they were using, reporting absence of pain. Our conclusion is that the treatment provided by the team has brought signific ant benefits and results to the improvement of the quality of life of the patients.

Key words: Bone transplant; Quality of life
Trabalho realizado no CAPPesq - HC FMUSP - Protocolo 704/00 Instituto de Ortopedia e Traumatologia do Hospital das Clínicas da Faculdade de Medicina da Universidade de São Paulo - IOT-HC FMUSP

1 - Assistente Social

2 - Diretora do Serviço Social Médico

3 - Doutor em Ortopedia Especialista em patologia do quadril. Médico Assistente chefe de equipe.

Endereço para correspondência: Rua Dr. Ovidio Pires de Campos, 333 Cerqueira Cesar - Cep 05403-010 - E-mail: s.social.iot@ hcnet.usp.br Trabalho recebido em 20/02/2003. Aprovado em 20/05/2003

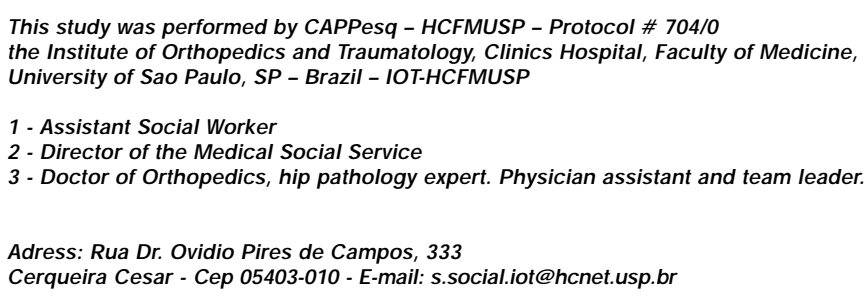




\section{INTRODUÇÃO}

A diretriz para reestruturação do Banco de Tecidos do Instituto de Ortopedia e Traumatologia do Hospital das Clínicas da Faculdade de Medicina da Universidade de São Paulo (IOT-HCFMUSP), foi baseada na lei no 9434, de 04 de fevereiro de 1997, regulamentada pelo decreto № 2268, de 30 de junho de 1997, que "dispõe sobre a remoção de órgãos, tecidos e partes do corpo humano para fins de transplantes e tratamento "(3,4). Esta reestruturação trouxe a possibilidade de atuação do Serviço Social junto à equipe interd isciplinar, que está constituída por: médicos ortopedistas, enfermeiros e assistente social. Após a indicação do enxerto ósseo, o Serviço Social tem se utilizado de instrumental específico para o conhecimento das seguintes variáveis: identificação do paciente, dados sócio demográficos, infra-estrutura socioeconômica e familiar, aspectos culturais e religiosos, nível de participação, aderência e mobilização do paciente e família frente ao tratamento, tendo em vista inseri-lo na fila única do Banco de Tecidos e o seguimento ambulatorial no pós-cirúrgico.

A indicação médica para o enxerto ósseo se faz necessária no tratamento das patologias que evoluem com perdas ósseas. Estas podem ser causadas por traumas, nas solturas de artroplastias do quadril ou nos tumores ósseos. 0 enxerto ósseo deverá repor o estoque ósseo perdido pelo paciente na evolução dessas patologias ${ }^{(1)}$.

O programa do Banco de Tecidos visa propiciar aos receptores a reabilitação física e social com a perspectiva de lhes oferecer uma melhor qualidade de vida.

O conceito de qualidade de vida tem recebido atenção cada vez maior, não só na literatura científica, como também nos meios de comunicação, nas campanhas publicitárias e plataformas políticas, tornando-se um termo muito estudado na sociedade atual. Este é um fenômeno complexo, com uma grande variedade de significados, tendo diversas possibilidades de enfoque para sua abordagem e inúmeras controvérsias teóricas e metodológicas para a exploração do conceito $^{(6)}$.

A qualidade de vida em sua essência, pode ser traduzida pela satisfação de viver. "O estado de satisfação ou de insatisfação constitui, na verdade, experiência de caráter pessoal e está ligado ao propósito de obtenção de melhores condições de vida. 0 grau de ajustamento às situações existentes, ou então o desejo de mudança, poderão servir para a presença ou ausência de satisfação"(5).

Segundo a Organização Mundial de Saúde - OMS, qualidade de vida foi definida como "a percepção do indivíduo de sua posição na vida, no contexto da cultura e sistema de valores, nos quais ele vive e em relação aos seus objetivos, expectativas, padrões e preocupações"(7).

Apesar de várias abordagens, os estudiosos concordam que é muito difícil medir qualidade de vida, uma vez que é um conceito subjetivo e intrínseco ${ }^{(8)}$.

Diante destas considerações, o Serviço Social propôs-se a realizar um estudo objetivando conhecer os benefícios e mudanças ocorridas após o tratamento cirúrgico dos pacientes do Grupo de Quadril Adulto e analisar se a expectativa bem como a melhoria na qualidade de vida destes pacientes foram atingidas. Espera-se também com este estudo, identificar e oferecer subsídios do ponto de vista social, favorecendo a equipe em sua atuação junto ao paciente.

\section{INTRODUCTION}

The guideline for the restructure of the Tissue Bank of the Institute of Orthopedics and Traumatology, Clinics Hospital, Faculty of Medicine, University of Sao Paulo (IOT-HCFMUSP) is based on Law \# 9434 of February 4, of 1997, regulated by Decree \# 2268 of J une 30, 1997 that "disposes about the removal of organs, tissues and parts of the human body for transplant and treatment purposes ${ }^{\prime \prime(3,4)}$. This allowed the Social Service to act together with the interdisc iplinary team, which is formed by orthopedists, nurses and assistant social worker. After the indication of a bone graft, the Social Senvice has made use of instrumentation that is specific for the knowledge of the following variables patient: identification, sociodemographic data, socioeconomic and family infrastructure, cultural and religious aspects, involvement level, adherence and mobilization of both the patient and his or her family towards the treatment, viewing to insert the patient into the single queue of the Tissue Bank and also the postsurgical ambulatorial follow-up.

Medical indication of bone graft is required in the treatment of pathologies that evolve with bone losses. These losses may be caused by traumas, in the loosening of hip arthroplasties or in bone tumors. The bone graft should replace the bone stock lost by the patient during the evolution of these pathologies ${ }^{(1)}$.

The program of the Tissue Bank views to provide those who receive it with physical and social rehabilitation, expecting to provide them with a better quality of life.

The concept of quality of life has gained increased attention not only in the scientific literature, but also in the communications media, in the advertising campaigns and political platforms, having become an expression that is very much studied in the current society. This is a complex phenomenon with a large variety of meanings and different possibilities to focus its approa$\mathrm{ch}$, as well as a number of technical and methodological controversies for the exploration of the concept ${ }^{(6)}$.

In its essence, quality of life can be translated into satisfaction to live. "The state of satisfaction or dissatisfaction constitutes, in reality, an experience of personal character and is linked to the aim of achieving the best life conditions. The degree of adjustment to existing situations, ot the desire to change, may allow the presence or absence of satisfaction"(5).

According to the World Health Organization (WHO), quality of life was defined as "the perception of the individual of his or her status in life, in the context of the culture and system of values in which the individual lives and in relation to his or objectives, expectations, standards and concerns ${ }^{\prime \prime(7)}$.

In spite of the many approaches, scholars agree that it is very difficult to measure quality of life, since it is a subjective, intrinsic concept $^{(8)}$.

Based on these considerations, the Social Service proposed the conduction of a study aiming at knowing the benefits and changes occurred after the surgical treatment of patients of the Adult Hip Group, and analyze whether the expectations and the improvement in the quality of life of these patients were achieved. It is also expected that this study will allow identifying and providing subsidies from the social perspective, favoring also the team as regards its work with the patients. 


\section{MATERIAL E MÉTODOS}

A lista única do Banco de Tecidos é constituída por pacientes oriundos dos diversos grupos especializados do IOT-HCFMUSP. 0 assistente social realiza, como rotina, a Avaliação Social de todos os pacientes inseridos na referida lista e acompanha individualmente cada caso nas fases pré e pós-cirúrgico, visando auxiliar pacientes e familiares nas situações sociais que possam interferir no decorrer do tratamento médico.

Nosso interesse incidiu sobre a problemática social dos pacientes do Grupo de Quadril Adulto pois, estes são portadores de desconforto causados pela dor que os limita para o exercício de sua profissão e nas atividades da vida diária.

No período de agosto de 1998 a junho de 2000 foram inseridos na lista única do Banco de Tecidos 145 pacientes para cirurgia de transplante ósseo, dos quais 50 foram operados, alguns reabilitados e outros em reabilitação. Foram delimitados para a pesquisa 20 pacientes ( $40 \%$ do total operado), cuja cirurgia e reabilitação transcorreu um período superior a 12 meses. Este é um perío do considerado ideal para que o paciente do Grupo de Quadril Adulto, receptor de tecido ósseo, retorne às suas atividades da vida diária.

A abordagem utilizada foi quanti-qualitativa. 0 instrumento de pesquisa foi um Formulário de Entrevista estruturado com questões fechadas e abertas, buscando analisar dados objetivos e subjetivos sobre a infra estrutura socioeconômica e familiar, aspectos do suporte para o tratamento, bem como da vida anteriore posterior ao enxerto ósseo. Foram construídos a partir da experiência do serviço social, considerando a participação dos familiares e de colaterais, no que se refere a: presença e disponibilidade para acompanhamento e cuidados no domicílio, colaboração entre os membros, mobilização de recursos materiais e de transporte para o tratamento e infra-estrutura habitacional. Também foi enfocada a percepção dos pacientes sobre sua qualidade de vida e analisada a classificação socioeconômica a partir do critério de Classificação Econômica Brasil, reformulado em $1997^{(2)}$.

A amostra do estudo foi abordada nos retornos ambulatoriais e convocada através de contatos telefônicos, quando esclarecemos o objetivo da pesquisa e solicitamos o consentimento para sua participação. Os dados foram coletados em entrevistas individuais, sendo que apenas 16 pacientes compareceram, em razão de óbito (2) e residirem em outro Estado (2).

\section{APRESENTAÇÃO DOS DADOS}

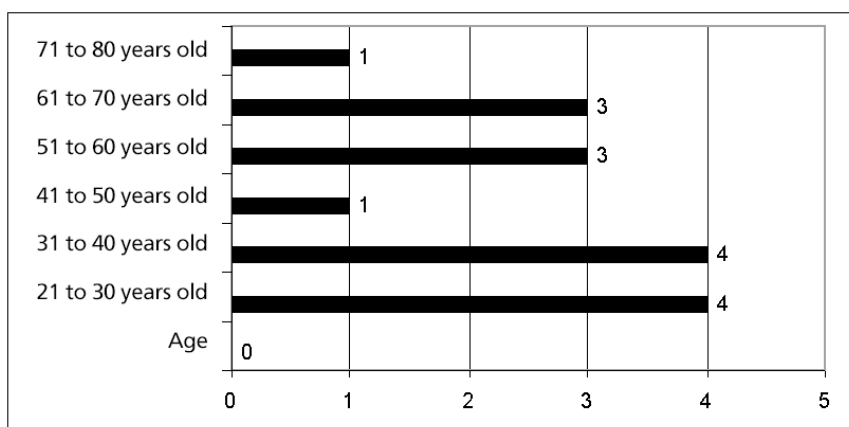

Gráfico 1 - Faixa etária de pacientes do grupo de quadril adulto operados com enxerto ósseo, entre agosto de 1998 e junho de 2000

Graph 1 - Age group of patients of the adult hip group operated with bone graft between August 1998 and J une 2000

\section{MATERIAL AND METHOD}

The single queue of the Tissue Bank is a list including patients from different specialized groups of the IOT-HCFMUSP. The assistant social worker performs routinely the Social Assessment of all patients inserted in the list and follows up individually each case during the preoperative and postoperative phases, viewing to help both patients and their families in social situations capable of interfering with the medical treatment.

Our concern was the social problem issues of patients of the Adult Hip Group, since they bear a series of discomforts caused by the pain limiting their possibilities to exert their professions and their daily life activities.

Between August 1998 and J une 2000, 145 patients were inserted in the Tissue Bank list for bone transplant surgery; 50 were operated, some were rehabilitated and others are in process of rehabilitation. For the investigation, 20 patients were selected ( $40 \%$ of the operated patients), whose surgeries and rehabilitation occurred in a period of over 12 months. This period is considered ideal for patients from the Adult Hip Group that receives a bone graft to return to their daily life activities.

The approach used was qualitative and quantitative. The investigation tool was an Interview Form structured with both open and closed questions attempting to analyze objective and subjective data on the socioeconomic and family infrastructure, aspects of support for the treatment, and life before and after the bone transplant. They were built based on the experience of the social worker, taking into account the participation of relatives and collaterals as regards their presence and availability to escort and take care of the patient at home, collaboration among members, mobilization of material and transportation resources for the treatment, and dwelling infrastructure. Also, the perception of patients regarding their quality of life was focused and the socioeconomic classification was analyzed based on criterion of Classification of Brazilian Economy in $1997^{(2)}$.

The sample of this study was approached in the returns to the ambulatory, and contacted by phone for interviews where we explain the objective of the investigation and request their informed consent to participate. The data were collected in individual interviews; only sixteen patients attended the interviews, due to death (2) or because they lived in other states ${ }^{(2)}$.

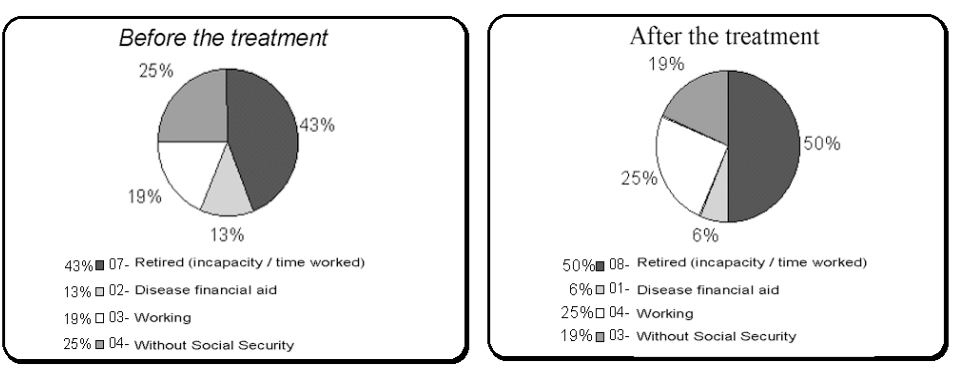

Gráfico 2 - Benefício previdenciário de pacientes do grupo de quadril adulto operados com enxerto ósseo, entre agosto de 1998 e junho de 2000

Graph 2 - Social Security of patients from the Adult Hip Group operated with bone graft between August 1988 and J une 2000 


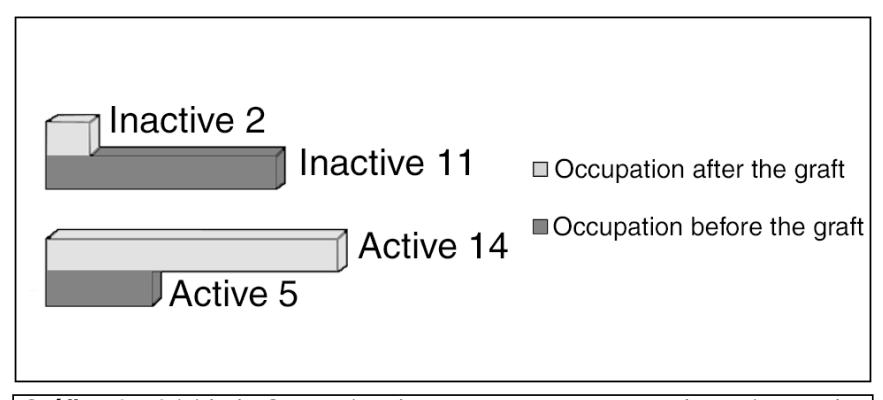

Gráfico 3 - Atividade Ocupacional antes e após o enxerto de pacientes do grupo de quadril adulto operados com enxerto ósseo, entre agosto de 1998 e junho de 2000

Graph 3 - Occupational Activity of patients from the Adult Hip Group operated with bone graft between August 1988 and J une 2000

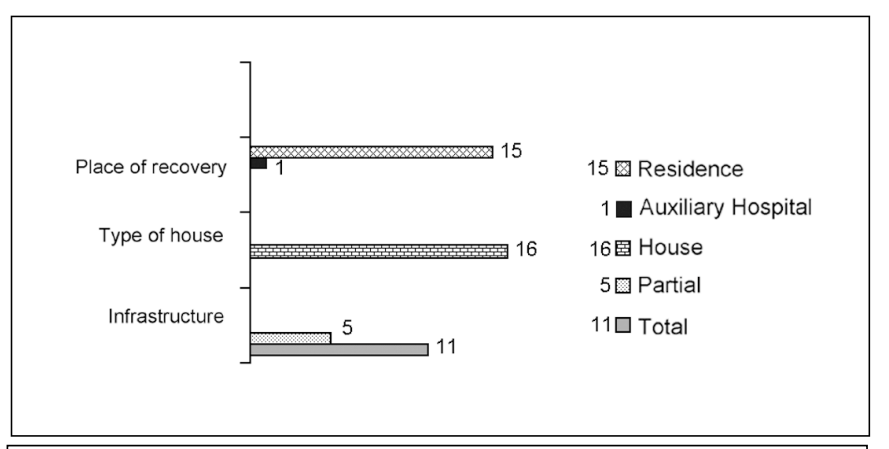

Gráfico 5 - Local de Recuperação/Tipo de Moradia/Infra-Estrutura Habitacional de pacientes do grupo de quadril adulto operados com enxerto ósseo, entre agosto de 1998 e junho de 2000

Graph 5 - Place of recovery / type of house / habitational infrastructure of patients of the adult hip group operated with bone graft between August 1998 and J une 2000
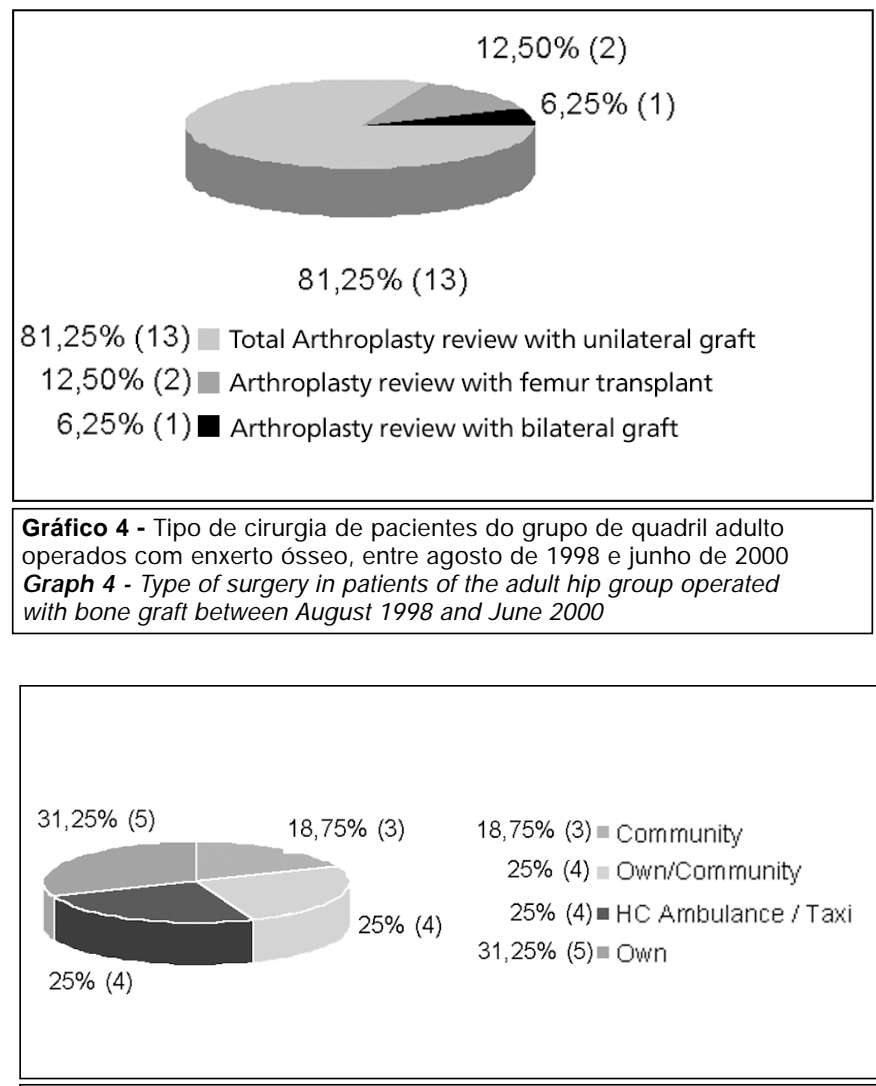

Gráfico 6 - Transporte utilizado pelos pacientes do grupo de quadril adulto operados com enxerto ósseo, entre agosto de 1998 e junho de 2000 Graph 6 - Transportation used by patients of the adult hip group operated with bone graft between August 1998 and J une 2000

\section{RESULTADOS}

Dos 16 pacientes pesquisados, constatamos que não houve predominância quanto ao sexo pois, $8(50 \%)$ eram do sexo feminino e $8(50 \%)$ do sexo masculino. A faixa etária revelou que 9 (56,25\%) pacientes tinham idade entre 21 a 50 anos, sendo que apenas $4(25 \%)$, a idade era superior a 60 anos, ou seja, considerados do grupo de pessoas idosas (Gráfico 1 ). Doze pacientes (75\%) eram católicos, não houve predominância quanto à cor, sendo $8(50 \%)$ brancos e $8(50 \%)$ da raça negra e destes $5(31,25 \%)$ eram pardos e $3(18,75 \%)$ eram negros. $7(43,75 \%)$ pacientes eram solteiros , $8(50 \%)$ casados e apenas $1(6,25 \%)$ divorciado.

\begin{tabular}{|l|l|l|}
\hline 1. Satisfactory & Number & $\%$ \\
\hline Experiences moderate pain and more mobility in the operated limb & 1 & 6.25 \\
\hline Does not experience pain, but has not yet released the props & 2 & 12.50 \\
\hline $\begin{array}{l}\text { Still has physical limitation because is waiting for total hip arthroplasty in } \\
\text { the other limb }\end{array}$ & 1 & 6.25 \\
\hline Experiences moderate pain & 2 & 12.50 \\
\hline Does not experience pain, but walks with limited movements & 1 & 6.25 \\
\hline \multicolumn{1}{|c}{ Subtotal } & 7 & 43.75 \\
\hline
\end{tabular}

\begin{tabular}{|l|l|l|}
\hline 2. Excellent & Number & $\%$ \\
\hline $\begin{array}{l}\text { Does not experience pain, abolished the orthopedic boot due to a 12-cm } \\
\text { shortening of lower limb }\end{array}$ & 1 & 6.25 \\
\hline Does not experience pain & 5 & 31.25 \\
\hline After the treatment, feels like he won the highest Lottery prize & 1 & 6.25 \\
\hline If he had not been operated, today he would be on a wheelchair & 1 & 6.25 \\
\hline $\begin{array}{l}\text { Considers that locomotion aspect is all right, although he started walking } \\
\text { without props only 15 days ago }\end{array}$ & 1 & 6.25 \\
\hline \multicolumn{1}{|c|}{ Subtotal } & 9 & 56.25 \\
\hline \multicolumn{1}{|c|}{ Total } & 16 & 100 \\
\hline
\end{tabular}

Tabela 1 - Benefícios pós-cirúrgicos obtidos pelos pacientes do grupo de quadril adulto operados com enxerto ósseo, entre agosto de 1998 e junho de 2000

Table 1 - Surgical benefits obtained by patients of the adult hip group operated with bone graft between August 1998 and J une 2000

\section{RESULTS}

In the 16 patients studied, we found that none of the sexes prevailed, since $8(50 \%)$ were females and $8(50 \%)$ were males. Nine $(50 \%)$ patients were in the $21-50$ age group; only $4(25 \%)$ were over 60 years, therefore considered as elderly (Graph 1 ). Twelve (75\%) patients were catholic and no color prevailed, since $8(50 \%)$ were caucasians and $8(50 \%)$ were of negro ethnics; of these, $5(31.5 \%)$ were mulattos and $3(10.75 \%)$ were negroes; $7(43.75 \%)$ were single, 8 $(50 \%)$ were married and only 1 $(6,25 \%)$ was divorced.

As to their origin, 10 (62.50\%) lived in the capital of the state and 
Quanto a procedência, a grande maioria, $10(62,50 \%)$ residia na capital, sendo que destes, 1 paciente residia em outro Estado anteriormente à cirurgia, mudando-se definitivamente para capital em virtude do tratamento. Os demais, 5 (31,25\%) procediam da Grande São Paulo e apenas $1(6,25 \%)$ era do interior do Estado.

O grau de instrução mostrou que $1(6,25 \%)$ dos pacientes nunca freqüentou escola e $1(6,25 \%)$ possuía o curso superior completo. Dos demais, 8 (50\%) efetivaram o Ensino Fundamental. Com relação a classificação socioeconômica, a pesquisa revelou que $37,5 \%$ pertencem à classe $C$, outros $37,5 \%$ à classe $D$ e $25 \%$ são pacientes da classe $E$, segundo o critério de Classificação Econômica Brasil.

Dos 16 pacientes pesquisados, 12 (75\%) eram vinculados ao sistema previdenciário anteriormente ao tratamento, sendo que destes apenas $3(18,75 \%)$ estavam inseridos formalmente no mercado de trabalho. Os $9(56,25 \%)$ restantes estavam em benefício previdenciário conforme Gráfico 2. Posterior ao tratamento, 1 $(6,25 \%)$ paciente passou a ser contribuinte da previdência social, estando vinculado formalmente ao mercado de trabalho.

Com relação a atividade ocupacional, verificou-se que 11 $(68,75 \%)$ pacientes estavam inativos antes do transplante ósseo. Após o transplante e decorridos 12 meses de reabilitação, constatou-se que $14(87,50 \%)$ pacientes retornaram, com alguns cuidados e moderações, às atividades ocupacionais (Gráfico 3).

Conforme Gráfico 4, no que se refere ao tipo de cirurgia, verificou-se que a grande maioria, $13(81,25 \%)$ pacientes, foi submetida à Revisão de Artroplastia Total de Quadril Unilateral com enxerto ósseo, 2 (12,50\%) pacientes Revisão de Artroplastia Total de Quadril Unilateral com transplante de fêmur e 1 (6,25\%) Revisão de Artroplastia Total de Quadril bilateral com enxerto ósseo. Há uma predominância de pacientes com estatura baixa e média baixa, pois $11(68,75 \%)$ pacientes encontram-se na faixa de $1,50 \mathrm{~m}$ a $1,65 \mathrm{~m}$ de estatura.

A massa corpórea foi analisada anterior e posteriormente ao tratamento e verificou-se que após a cirurgia $9(56,25 \%)$ pacientes tiveram aumento de peso.

Com relação ao suporte social no decorrer do tratamento, verificou-se que a participação da família foi satisfatória para 13 $(81,25 \%)$ pacientes. Todos residiam em casa, porém $5(31,25 \%)$ pacientes possuíam casas desprovidas de infra-estrutura total, localizadas em terrenos acidentados. Cerca de 10 (62,50\%) pacientes apresentaram renda satisfatória no decorrer do tratamento.

No que se refere à expectativa dos pacientes com relação ao tratamento, o resultado revelou que a grande maioria $15(93,75 \%)$, esperava obter um ou mais benefícios, sendo que apenas 1 $(6,25 \%)$, por acreditar que sua situação era irreversível, esperava pela diminuição da dor.

Foram analisados alguns aspectos da vida pessoal dos pacientes e verificou-se que enfrentavam as seguintes dificuldades:

Físico: $100 \%$ dos pacientes tiveram dificuldades para dormir, andar, sentar, dirigir, higienizar-se ou permanecer muito tempo na mesma posição devido a dor, perda da mobilidade e claudicação.

Locomoção: 93,75\% dos pacientes referiram dificuldades, acentuadas pela dor, para subir em ônibus e andar, sendo que destes $12(75 \%)$ evitavam andar e só saiam de casa para ir ao
1 patient lived in a different state before the surgery, having moved definitively to the Greater Sao Paulo because of the treatment of the others, $5(31,25 \%)$ were from the Greater São Paulo and only $1(6.25 \%)$ was from the hinterland of the state.

One $(6.25 \%)$ of the patients never attended school and one $(6.25 \%)$ had a college degree. Eight $(50 \%)$ had completed Elementary School. As to the socioeconomic conditions, $37.5 \%$ belonged to the $\mathrm{C}$ class; $37.5 \%$ to $\mathrm{D}$ class and $25 \%$ to the $\mathrm{E}$ class, according to the Classification of Brazilian Economy.

Of the 16 patients investigated, 12 (75\%) were linked to the social security system before the treatment, but only $3(18.75 \%)$ of them were formally inserted in the work market. The other 9 $(56.25 \%)$ were pensioners (Graph 2 ). After the treatment, 1 $(6.25 \%)$ patient entered the social security system and was formally linked to the work market.

As to occupational activities, $11(68.75 \%)$ patients were inactive before the bone transplant. After the surgery and after 12 months of rehabilitation, $14(87.50 \%)$ patients were back to their occupational activities, although with some caution and moderation (Graph 3).

As shown in Graph 4, as regards the type of surgery, most patients (13, that is, $81.25 \%$ ) underwent a Revision of Unilateral Total Hip Arthroplasty with bone graft, 2 (12.50\%) underwent a Revision of Unilateral Total Hip Arthroplasty with femur transplant and 1 (6.25\%) underwent a Revision of Bilateral Total Hip Arthroplasty with bone graft. Patients with low and medium heights prevailed: 11 (68.75\%) were 1.50 to $1.65 \mathrm{~m}$ tall.

The body mass was analyzed before and after the treatment and after the surgery 9 (56.25\%) patients had gained weight.

As to social support during the treatment, family involvement was satisfactory in $13(81.25 \%)$ patients. All lived in houses, although $5(31.25 \%)$ of them lived in houses with no infrastructure at all, located in terrains places. Approximately 10 (62.50\%) patients earned satisfactory incomes during the treatment.

As to the patients expectations regarding the treatment, most of them (15, that is $93.75 \%)$ expected to obtain one or more benefits and only 1 (6.25\%) expected a decrease in pain, since his situation was irreversible.

Some aspects of the personal life of the patients were analyzed and showed that they faced the following difficulties:

Physical: $100 \%$ of the patients had difficulty to sleep, walk, sit down, drive, wash themselves or stay in the same position for a long time due to pain, loss of mobility and claudication.

Locomotion: $93.75 \%$ of the patients reported difficulties (enhanced by pain) to enter a bus, and walk; of these, $12(75 \%)$ avoided walking and went out of the house only to go to the doctor; $3(18.75 \%)$ reported that, since they feared losing their jobs, and due to shame and an inferiority complex. They did use the orthopedic devices prescribed by the physician. Only 1 patient reported that he did not feel pain, although he was affected by loss of mobility.

Occupational: in general, the occupational activities were performed with extreme difficulty due to pain and physical limitation. Some adaptations occurred such as change in work hours to avoid traffic, higher chairs and changes in the height of the table and the kitchen sink. 
médico e $3(18,75 \%)$ referiram que, por receio de perder o emprego, vergonha e complexo de inferioridade, não usavam o equipamento ortopédico prescrito pelo médico. Apenas 1 paciente referiu não ter dor, no entanto era acometido pela perda de mobilidade.

Profissional: as atividades profissionais eram exercidas, em geral, com muita dificuldade devido a dor e limitação física. Houve adequações como: mudança no horário de trabalho para evitar o trânsito, cadeiras mais altas e ao nível da mesa e da pia da cozinha.

Social: o isolamento social esteve presente em 15 (93,75\%) dos casos, salientando-se que para $6(37,50 \%)$ pacientes 0 isolamento foi total em razão da dor e limitação física.

Lazer: apenas $1(6,25 \%)$ referiu ter vida normal neste aspecto. Os demais, 10 (62,50\%) praticavam com dificuldades, futebol, vôlei, freqüentavam igreja, estádios de futebol, festas, shopping e cinemas e $5(31,25 \%)$ não praticavam nenhum tipo de lazer devido a dor, limitação física, depressão, preconceito e dificuldades financeiras.

Com relação aos benefícios obtidos após a cirurgia, os 16 pacientes pesquisados (100\%) consideram que a cirurgia trouxe algum tipo de benefício que tenha contribuído para a melhoria de sua qualidade de vida. Na avaliação feita pelos pacientes com relação aos benefícios obtidos com a cirurgia, verificou-se que $9(56,25 \%)$ consideraram os resultados excelentes e $7(43,75 \%)$ satisfatórios, porém com significativa melhoria da qualidade de vida.

Foram analisados os mesmos aspectos em que os pacientes apresentavam dificuldades antes da cirurgia e verificou-se que ocorreram as seguintes mudanças posteriormente ao tratamento cirúrgico:

Físico: a ausência total da dor e da limitação física proporcionou melhor conforto para sentar e dormir a $13(81,25 \%)$ pacientes, dos quais $9(56,25 \%)$ referiram insegurança para dormir do lado operado, dobrar o quadril para higienizar os pés, ficar de pé por muito tempo e praticar algum tipo de atividade que exija esforço físico.

Locomoção: Apenas $3(18,75 \%)$ pacientes referiram que, dore claudicação, mesmo não sendo significativa, ainda os incomoda na locomoção. Apenas $6(37,50 \%)$ pacientes, se utilizam de bengala para algumas situações como: atravessar ruas e avenidas e ficar em fila de agências bancárias. Alegam que o uso deste equipamento Ihes proporciona maior segurança e proteção.

Profissional: Verificamos a inclusão de 1 paciente no mercado trabalho, sendo este seu primeiro emprego, somando portanto 4 (25\%) pacientes inseridos no mercado formal de trabalho. $9(56,25 \%)$ pacientes passaram a exercer atividades moderadas, com cautela, no lar, ou no próprio estabelecimento comercial e atividades de costuras.

Social: para 14(87,50\%) pacientes a vida social passou a ter outro significado proporcionando-Ihes participação ativa nas atividades sociais.

Lazer: $14(87,50 \%)$ pacientes passaram a praticar algum tipo de lazer sem dificuldades. Apenas $6(37,50 \%)$ destes, referem ainda moderação e cautela neste aspecto. $2(12,50 \%)$ pacientes referem pouca participação na vida social e lazer em virtude da ausência de companhia e dificuldades financeiras, ressaltando que suas residências são desprovidas de infra estrutura, possuem escadas e são localizadas em terreno acidentado, o que dificulta a sua locomoção. Salienta-se ainda que estes 2 pacientes aguardam cirurgia no outro membro.
Social: social isolation was present in 15 (93.75\%) of cases, and it is worth noticing that for $6(37.50 \%)$ patients, isolation was total as a result of pain and physical limitation.

Leisure: only 1 (6.25\%) reported having a normal life as regards this aspect. The others (10, that is, $62.50 \%$ ) practiced, although with difficulty, soccer and volleyball, went to church, to soccer games, parties, shopping centers and movie theaters; 5 $(31.25 \%)$ had no leisure at all due to pain, physical limitation, depression, prejudice and financial problems.

As to the benefits gained after the surgery, all 16 (100\%) patients studied considered that the surgery brought some kind of advantage contributing to improve their quality of life. In the assessment made by the patients as regards the benefits from surgery, $6(56.25 \%)$ reported that they had excellent results and 7 $(43.75 \%)$ reported satisfactory results, although with significant improvement in their quality of life.

The same aspects were analyzed in which the patients had difficulties before the surgery, and it was found that after the treatment changes had occurred, such as:

Physical: the total absence of pain and physical limitation provided more comfort to sit down and to sleep to $13(81.25 \%)$ patients, of which 9 (56.25\%) reported insecurity to sleep on the operated side, bend the hip to clean their feet, stand up for longer periods and practice some type of activity requiring physical effort.

Locomotion: Only 3 (18.75\%) patients reported that pain and claudication, although non significant, still bother them as they walk. Only $6(37.50 \%)$ patients use canes in some situations such as cross streets or avenues and stay in a bank queue. They say that the use of the devices provides them with more safety and protection.

Occupational: We found that 1 patient was included in the work market and that it was his first job; therefore, there were 4 ( $25 \%)$ patients inserted into the formal work market. Nine $(56.25 \%)$ patients started exerting moderate activities, with caution, at home or in their own business, or sewing.

Social: for $14(87.50 \%)$ patients, social life started having a different meaning, providing them with active involvement in social activities.

Leisure: $14(87.50 \%)$ patients started having some kind of leisure with no difficulties. Only $6(37.50 \%)$ of these reported some moderation and caution in this aspect. Two (12.50\%) patients reported low involvement in social life and leisure due to the absence of company and financial problems, emphasizing that their homes have no infrastructure, have stairs and are located in rough terrains, making their locomotion more difficult. It is worth noticing that these 2 patients are waiting to have the other limb operated. 


\section{DISCUSSÃO}

Os resultados evidenciam que anteriormente à cirurgia de enxerto ósseo, os pacientes do Grupo de Quadril Adulto apresentam dor, o que Ihes causa limitação física e dificuldade de locomoção nas mais simples atividades da vida diária. Estes pacientes convivem com outros problemas, entre eles o isolamento social, a limitação na participação em atividades de lazer e necessidade de adaptações com relação ao exercício de atividades profissionais.

A pesquisa nos possibilitou uma maior reflexão sobre as condições em que vivem os pacientes que necessitam de enxerto ósseo e das dificuldades por eles vivenciadas.

A análise da vinculação ao sistema previdenciário anteriormente ao tratamento nos proporcionou importantes informações à este respeito, pois verificou-se que a grande maioria ,12 (75\%) possuía algum vínculo previdenciário, porém apenas $3(18,75 \%)$ estavam inseridos formalmente no mercado de trabalho. Os demais estavam afastados por aposentadoria ou auxílio doença. Posterior ao tratamento, $1(6,25 \%)$ paciente passou a ser contribuinte da previdência social, estando vinculado formalmente ao mercado de trabalho.

$\mathrm{Na}$ análise da atividade ocupacional, verificou-se que, após a instalação da doença e enquanto o paciente aguardava a convocação para o transplante ósseo, $11(68,75 \%)$ pacientes estavam inativos. Após o transplante ósseo e decorridos 12 meses de reabilitação, constatou-se que $14(87,50 \%)$ pacientes retornaram, com alguns cuidados e moderações, às atividades ocupacionais (Gráfico 3). Se compararmos este dado à situação previdenciária, verifica-se que apenas 1 inseriu-se no mercado formal de trabalho, porém o número de pacientes que passou a exercer algum tipo de atividade ocupacional, mesmo estando em benefício previdenciário, foi significativo.

Com relação ao tipo de cirurgia, verificou-se que apesar da grande maioria ter sido submetida à Revisão de Artroplastia Total de Quadril Unilateral com enxerto ósseo, observou-se que os 2 $(12,50 \%)$ pacientes que se submeteram à Revisão de Artroplastia Total de Quadril Unilateral com transplante de fêmur e 1 (6,25\%) paciente que fez Revisão de Artroplastia Total de Quadril bilateral com enxerto ósseo, é que enfrentaram maiores dificuldades no período de reabilitação em função da dependência física por um perío do maior.Para estes $3(18,75 \%)$ o suporte familiar foi prejudicado pois, se referiam a pacientes cujas famílias eram compostas por menor número de membros e apresentaram dificuldades para oferecer o suporte necessário na reabilitação pós cirúrgica . Estes casos são os que necessitam maior atenção da equipe interprofissional, bem como da intervenção do Serviço Social.

A avaliação da moradia dimensionou as dificuldades enfrentadas por 5 pacientes que residiam em casas desprovidas de infra estrutura total e localizadas em terrenos acidentados, o que dificultou 0 acesso destes pacientes na residência e para os retornos ambulatoriais. Neste sentido 1 paciente necessitou recuperarse em hospital de retaguarda, não podendo retornar para sua residência (Gráfico 5). Cerca de 10 (62,50\%) pacientes apresentaram renda satisfatória no decorrer do tratamento. Observou-se que, devido a cirurgia, o paciente necessita de cuidados especiais na remoção do Hospital para residência e vice-versa, sendo que a mobilização dos familiares evidenciou-se de forma bastante participativa, conforme verifica-se no Gráfico 6.

Nos comentários dos pacientes e na avaliação feita por eles a

\section{DISCUSSION}

The results show that before the bone graft surgery, patients of the Adult Hip Group experienced pain, causing them physical limitation and locomotion problems even in the simplest activities of daily life. These patients live with other problems, among them social isolation, limitation in the involvement in leisure activities and need to adapt as regards exerting occupational activities.

The study allowed us to reflect more deeply about the conditions surrounding patients requiring bone grafts, as well as the difficulties they live with.

The analysis of the link to the social security system provided us with important information about this, since we found that the great majority $(12$, that is, $75 \%$ ) had some social security link, while only 3 (18.75\%) were formally inserted in the work market. The others were retired or received disease financial aid. After the treatment, $196.25 \%$ ) patient entered the social security system and was formally linked to the work market.

The analysis of occupational activity showed that after the onset of the disease and while the patient waited for the bone transplant, $11(68.75 \%)$ patients were inactive. After the bone transplant and after 12 months of rehabilitation, $14(87.50 \%)$ patients had returned to their occupational activities, although with caution and moderation (Graph 3 ). Is we compare these data with the social security situation, we see that only 1 patient entered the formal work market, but the same number of patients who started having some kind of activity was significant, although they were living on social security.

As to the type of surgery, it was found that, although the great majority had been subjected to Revision of Unilateral Total Hip Arthroplasty with bone graft, it was found that the $2(12.50 \%)$ patients subjected to Revision of Unilateral Total Hip Arthroplasty with femur graft and 1 (6.25\%) patient subjected to Revision of Unilateral Total Hip Arthroplasty with bone graft were the ones facing the most difficulties during the rehabilitation period due to physical dependence, for a longer period. In these $3(18.75 \%)$ patients, the family support was impaired, since they had small families who could not provide the postoperative support required. Such cases need much attention not only from the multidisciplinary team, but also from Social Service.

The assessment of their dwellings set the dimensions of the difficulties faced by 5 patients who lived in houses with no infrastructure at all, located in rough terrains, which prevented an easy access to their homes and did not facilitate their visits to the ambulatory. One patient had to recover in a rearguard hospital and could not retum home (Graph 5). Approximately 10 (62.50\%) patients earned satisfactory incomes during the treatment. It was noticed that, due to the surgery, the patient requires special care in the transportation to and from the Hospital and home and vice versa and their families were deeply involved in this aspect, as seen in Graph 6.

Based on the comments of patients and on their evaluation of the benefits provided by the treatment, we noticed that, for the group that considered the result Excellent (9, that is, 56.25\%) aspects such as total absence of pain, the fact that they did not use the orthesis or the orthopedic device anymore and the ab- 
respeito dos benefícios obtidos após a cirurgia, observamos que o grupo que considerou o resultado Excelente, 9 (56,25\%), os aspectos como a ausência total de dor, o desuso de órtese ou do equipamento ortopédico e a ausência da limitação física, proporcionaram um novo sentido às suas vidas. Para os demais, $7(43,75 \%)$, apesar de sentirem dor pouco relevante, com os movimentos físicos limitados e usando equipamento ortopédico, a melhoria da qualidade de vida também foi bastante significativa. Acreditamos que para este grupo o sucesso ainda não foi excelente pois, aqui incluem-se pacientes portadores de outras patologias associadas, com cirurgias mais complexas e, portanto, necessitando de um tempo maior para se avaliar o resultado final do tratamento.

A procedência é um dado relevante para a equipe do Banco de Tecidos, em função do suporte social e familiar necessários no pós-cirúrgico e seguimento ambulatorial.

Conforme afirma Forattini(5) a qualidade de vida em sua essência, pode ser traduzida pela satisfação de viver e o estado de satisfação está ligado ao propósito de obtenção de melhores condições de vida. Acreditando no propósito de oferecer melhores condições de vida aos pacientes que necessitam de enxerto ósseo, é que o Grupo de Quadril deste Instituto considera que programas desta natureza devem ser incentivados pelas equipes que atuam com pacientes portadores desta patologia e pelas autoridades da área da saúde.

\section{CONCLUSÃO}

Embora as mudanças sejam gradativas, conclui-se que a diminuição da dor e da limitação física após a cirurgia, são aspectos que proporcionam conforto ao paciente, facilitando sua locomoção, garantindo-Ihes uma participação mais ativa nas atividades sociais, de lazer e no trabalho.

Verificou-se que a participação da família, é de fundamental importância, pois os dados apontam que a colaboração, presença e disponibilidade dos familiares favorecem o resultado final do tratamento proporcionado pela equipe.

Neste processo, tão complexo, é necessário uma efetiva assistência individualizada por parte dos profissionais junto aos pacientes desde a captação, processamento, distribuição e utilização dos tecidos. A atuação conjunta da equipe interprofissional é de fundamental importância para obtenção de benefícios ao paciente e sua família.

\section{REFERÊNCIAS BIBLIOGRÁFICAS}

1. Bernabé AC. Revisão de Artroplastia do Quadril. Reavaliação Clínica e Radiológica de 40 casos. [Tese]. São Paulo:Faculdade de Medicina da Universidade de São Paulo de São Paulo; 1996.

2. CRITÉRIO DE CLASSIFICAÇÃO ECONÔMICA BRASIL - ABA, ANEP, ABIPEME, 1997. Reformulação do Critério anterior, (ABA - ABIPEM). Disponível em: < http://www.anep.org.br/mural/anep/ > . Acesso em:4 dez.1997.

3. DIÁRIO OFICIAL DA REPÚBLICA FEDERATIVA DO BRASIL. LEI N N. 9434, de 4 de Fevereiro de 1997. Dispõe sobre a remoção de órgãos, tecidos e partes do corpo humano para fins de transplantes e tratamento e de outras providências. Diário Oficial da União, Brasília, 05 de fev. 1997, seção 01, n.o 25, p. 2191.

4. DIÁRIO OFICIAL DA REPÚBLICA FEDERATIVA DO BRASIL. DECRETO N.o 2268 de 30 de junho de 1997. Regulamenta a lei n. .9434 , de 04 de Fevereiro de 1997, que dispõe sobre a remoção de órgãos, tecidos sence of physical limitation provided their lives with a new meaning. For the others ( 7 , that is, $43.75 \%$ ), although their pain was not so relevant and their physical movements were still limited and they were still making use of orthopedic devices, the improvement in their quality of life was also significant. We believe that for this group the success was not excellent yet because the group includes patients with associated pathologies and more complex surgeries, therefore requiring a longer period of time to evaluate the final result of the treatment.

The orig in is a relevant datum for the team in the Tissue Bank, as a function of social and family support required during the postoperative period and the ambulatorial follow-up.

According to Forattini(5), the quality of life in its essence can be translated by the satisfaction to live, and by the state of satisfaction is bound to the purpose of obtaining better life conditions. Believing in the intention to provide better life conditions to patients requiring bone grafts, the Hip Group of this Institute considers that programs of this nature should be stimulated by the teams that work with patients with this pathology and by the health area authorities.

\section{CONCLUSIONS}

Although the changes are gradual, the conclusion is that the reduction of pain and physical limitation after the surgery are aspects that provide the patient with comfort, making their locomotion easier and assuring them a more active participation in social, leisure and occupational activities.

It was found that family involvement is most important, since the data show that family collaboration, presence and availability contribute favorably to the final result of the treatment provided by the team.

This already complex process requires effective individual assistance from the professionals working with the patients, from the collection, processing, and distribution until the use of the tissues. The joint action of the multidisciplinary team is fundamental to obtain benefits for the patients and their families.

e partes do corpo humano para fins de transplantes e tratamento e de outras providências. Diário Oficial da União, Brasília, 01 de jul. 1997, n.ำ 123.

5. Forattini OP. Qualidade de vida e meio urbano: a cidade de São Paulo. Rev. Saúde Pública 25:75-86, 1991.

6. Kimura M. Qualidade de Vida - Indicadores de Qualidade de Vida Unidades de Terapia Intensiva e Assistência de Enfermagem. [Docência]. São Paulo:Escola de Enfermagem da Universidade de São Paulo; 1999.

7. ORGANIZAÇÃO MUNDIAL DE SAÚDE. (WHOQOL GROUP, 1994), 2000. Disponível em:<http:// www.ufrgs.br/psiq >. Acesso em: 25 ago.2000.

8. Silva EB, Ciampone MHT. "Ser/estar amputado - deficiência/qualidade de vida - percepção da clientela inserida em programa de reabilitação". Rev. Enferm. HCFMUSP 2:13-19, 1998. 